\title{
A Study of Demographics Influencing on Consumer Behavior and Attitude towards Brand Equity of Optical Business in Thailand
}

\author{
Piyachat Laoviwat, Pramote Suppapanya, and Khanchitpol Yousapronpaiboon, Member, IACSIT
}

\begin{abstract}
The objectives of this study were to examine whether demographics could influence on the consumer behavior and attitude towards brand equity of optical business. The sample was 350 secondary and high school students in Thailand using self-administered questionnaire for data collection. The major consumer' reason to purchase eyeglasses was optician's specialist; the reason to wear eyeglasses was having myopia; and the people influencing in purchasing eyeglasses was oneself. The score of consumer attitude towards brand equity were brand association, perceive quality, brand loyalty, and brand awareness, respectively. The hypothesis test results indicated that gender, education, and household income influenced consumer behaviors, at statistical significance level 0.05. It also found that education influenced brand loyalty and household income influenced brand awareness, at statistical significance level 0.05 .
\end{abstract}

Index Terms-Brand equity, consumer behavior, demographics, optical business.

\section{INTRODUCTION}

Nowadays, a growing average in the usage of electronic devices, especially smartphones, tablets, pc and computers are increasing in consumer behavior trend. One such technology is smartphone, which has shown promise as a delivery mechanism for health behavior interventions. These devices have become a more pervasive part of society with usage rates increasing exponentially [1]. For example, in Thailand, some $52 \%$ of teenager populations (i.e., $15-24$ year olds) uses electronic device, $38 \%$ of while in younger populations (i.e., 6-14 year olds). Thai consumer increasing reliant on such devices, spending long hours looking at digital screens, this led to more people encountering eyes problem (myopia) or Computer Vision Syndrome [2].

Eyewear market in Thailand has an optimistic outlook for growth over the forecast period. There are a number of supporting factors such as continuous growth in the population of eye problems, sun protection purposes and demand for fashionable eyewear products. Players would expect to stimulate further demand by introducing new value-added product collection, more product variety, strengthening brand awareness and applying different

Manuscript received March 6, 2014; revised May 15, 2014.

The authors are with College of Graduate Study in Management (MBA), Khon Kaen University, Bangkok Campus, Thailand (e-mail: 1.piyahat@hotmail.com, yousapro@yahoo.com). marketing strategies. As a one-stop service channel, optical specialist retailers were the preferred distribution outlets for Thai consumers when purchasing eyewear products. Consumers have confidence that they are purchasing quality products and genuine brands through this channel [3].

Consumer behavior and brand equity are significant in marketing consumer goods and services [4]. In eyewear business, demographics associated with consumer behavior [5]-[7] as well as brand equity [5]. Therefore, the objectives of this paper aim to study of demographics associated with consumer behavior and demographics influencing on attitude towards brand equity of optical business in Thailand.

\section{LITERATURE REVIEW}

\section{A. Consumer Behavior Concept}

Consumer behavior is defined as a process of consumer making a decision regarding the purchase, use, and disposal of goods and services. The model of consumer buying behavior compounded with decision-making process is external stimuli, which consist of marketing stimuli (product, price, place, promotion), and other stimuli (economy, technology, law and political, culture) [8]. The key question is how consumers are likely to response to the various stimuli (product and service selection, brand selection, dealer choice, reseller selection, purchase timing, repurchase interval, and purchase amount). The Black Box model devised, explained the hidden nature (internal stimulus) of consumer decision-making process. The buyer's black box containing the buyer's characteristics (attitude, motivation, perception, lifestyle, personality, knowledge) and decision-making process (problem recognition, information research). Much consumer research was undertaken to learn more about six questions (what consumers buy, who buy, how they buy, when they buy, where they buy, and why they buy) [9]

\section{B. Brand Equity Concept}

As branding is a very complex concept, it is important to determine which of many branding elements should be included in the model [10]. The goods or services of a competitor are preceded by using the four elements to build brand equity [11]. Component of the brand equity is divided into the following four aspects. Brand awareness shows the strength of the brand in the minds of consumers which can be checked from recognition and recall of the brand [12]. Brand association can be classified into product attributes, a link that helps in brand positioning, recognition of the quality of the product and technology leadership. Perceived quality 
refers to how to consider the quality of the product, such as a performance of goods, a reliability of products with consistent quality, and service quality. Brand loyalty is the relationship between consumer and brand that represents the purchase intent of consumers that will not switch to another brand [13].

\section{Previous Studies}

Q. S. You, L. J. Wu, J. L. Duan, Y. X. Luo, L. J. Liu et al. [6] studied factors associated with myopia in school children in China: The Beijing childhood eye study found that myopia in school children in Greater Beijing was associated with age $(p<0.001)$, gender $(p<0.001)$, and household income $(p<$ $0.001)$.

Anyanee [7] studied the consumer behavior when purchasing eyeglasses and investigated factor affecting the decision-making of consumer. The results showed that the factors which influence consumer behavior on decision making towards purchasing eyeglasses are; the professionalism of staff, post-sales services (20.1-23.4\%). The frequency in purchase eyeglasses from optical shop is less once a year.

In addition, Wannapa [14] studied brand equity of contact lens influencing on consumer behavior. The results found that income factor was a significant difference of brand awareness and brand loyalty.

\section{METHOD}

This study adopted a quantitative approach by self-administered questionnaire as a survey tool. All data were collected from 350 secondary and high school students, who were the customers of optical business, in Thailand. The analysis tools adopted in this study were descriptive and inferential statistical tools. The study questionnaire consists of 3 following sectors. The first is demographic characteristics, such as gender, education, and household incomes of parents, the second is a consumer behavior in decision making for eyeglasses purchasing questionnaire, and the last is an attitude towards brand equity, consisting brand awareness, brand association, perceived quality, and brand loyalty. This study adopted a 5-point Likert type scale, which is ranging from strongly disagree $($ score $=1)$ to strongly agree (score $=5$ ) to access attitude of secondary and high school students. The Cronbach alpha result of pilot test of the reliability of the questionnaire was 0.92 , which was higher than 0.80 on acceptable [15].

\section{RESULTS}

\section{A. Descriptive Results}

The demographic information includes the following characteristics; gender, year of education, and household incomes. The demographic information shown in Table I is based on frequency distributions and percentage.

From 350 respondents of this study, 113 (32.3\%) were male and $237(67.3 \%)$ were female. For year of education, 98 (28.0\%) were grade 7-9 and 252 (72.0\%) were grade 10-12. The average monthly incomes of the respondents' parents were less than 20,000 Baht at 111 (31.7\%), 20,001-40,000 Baht at $172(49.1 \%), 40,001-60,000$ Baht at $46(13.1 \%)$, and more than 60,001 Baht at $21(6.1 \%)$.

TABLE I: DEMOGRAPHIC DATA OF THE SAMPLE $(N=350)$

\begin{tabular}{llll}
\hline Variables & & $\boldsymbol{N}$ & $\boldsymbol{\%}$ \\
\hline Gender & Male & 113 & 32.3 \\
& Female & 237 & 67.3 \\
Education & Grade 7-9 & 98 & 28.0 \\
& Grade 10-12 & 252 & 72.0 \\
Household & Less 20,000 Baht & 111 & 31.7 \\
income & 20,001-40,000 Baht & 172 & 49.1 \\
& 40,001-60,000 Baht & 46 & 13.1 \\
& More than 60,001 Baht & 21 & 6.1 \\
\hline
\end{tabular}

The major consumer' reason to purchase eyeglasses was optician's specialty; the reason to wear eyeglasses was having myopia; and the people influencing in purchasing eyeglasses was oneself. The frequency of purchasing eyeglasses was less than twice per year. The most convenience place to purchase eyeglasses was regular/family store. The budget of purchasing eyeglasses was less than 2,000 baht per time.

From Table II, the ranking score of consumer attitude towards brand equity were brand associations, perceive quality, brand loyalty, and brand awareness, respectively.

TABLE II: LEVEL OF CONSUMER'S ATTITUDE TOWARDS BRAND EQUITY

\begin{tabular}{ccc} 
& $(N=350)$ & \\
\hline Brand equity & $\overline{\mathrm{X}}$ & S.D. \\
\hline Brand awareness & 3.55 & 0.626 \\
Brand associations & 4.02 & 0.616 \\
Perceive quality & 4.00 & 0.527 \\
Brand loyalty & 3.84 & 0.643 \\
\hline
\end{tabular}

\section{B. Hypotheses Testing Results of Consumer Behavior}

The results of the hypothesis tests for the associations between demographics and consumer behavior, using chi-square statistics, are as the following: For gender, there were associations with the people influencing in purchasing eyeglasses and the most convenience place to purchase eyeglasses; For education, there was association with the people influencing in purchasing eyeglasses; For household income, there was association with the budget of purchasing eyeglasses, as shown Table III.

TABLE III: DEMOGRAPHICS AND CONSUMER BEHAVIOR

\begin{tabular}{|l|c|c|c|}
\hline \multicolumn{1}{|c|}{ Demographics } & $\begin{array}{c}\text { Gender } \\
(p)\end{array}$ & $\begin{array}{c}\text { Education } \\
(p)\end{array}$ & $\begin{array}{c}\text { Household } \\
\text { income } \\
(p)\end{array}$ \\
\hline $\begin{array}{l}\text { consumer behavior } \\
\text { eyeglasses. }\end{array}$ & 0.528 & 0.114 & 0.615 \\
$\begin{array}{l}\text { 2. The most reason to wear } \\
\text { eyeglasses. }\end{array}$ & 0.064 & 0.643 & 0.168 \\
$\begin{array}{l}\text { 3. The most influential } \\
\text { who makes decision to } \\
\text { purchase eyeglasses. } \\
\text { 4. The frequency of } \\
\text { purchasing eyeglasses per } \\
\text { year. } \\
\text { 5. The most convenient } \\
\text { place to purchase } \\
\text { eyeglasses } \\
\text { 6. Budget to purchase } \\
\text { eyeglasses per time. }\end{array}$ & $0.021^{*}$ & $0.003^{*}$ & 0.834 \\
\hline Significant level 0.05 & 0.037 & 0.072 & 0.097 \\
\hline
\end{tabular}

*Significant level 0.05 


\section{Hypotheses Testing Results of Brand Equity}

The results of hypothesis test for the influencing of gender to brand equity, using t-test with significant level 0.05 , showed that there were no significant differences in attitude towards brand equity in all dimensions, as shown Table IV.

TABLE IV: GENDER AND BRAND EQUITY

\begin{tabular}{|l|c|c|c|c|}
\hline \multirow{2}{*}{ Brand Equity } & \multicolumn{2}{|c|}{ Mean of gender } & \multicolumn{2}{|c|}{} \\
\cline { 2 - 5 } & Male & Female & $t$ & Sig. \\
\hline $\begin{array}{l}\text { Brand } \\
\text { awareness }\end{array}$ & 3.56 & 3.54 & 0.247 & 0.805 \\
\hline $\begin{array}{l}\text { Perceived } \\
\text { quality }\end{array}$ & 3.99 & 4.01 & -0.421 & 0.674 \\
\hline $\begin{array}{l}\text { Brand } \\
\text { associations }\end{array}$ & 3.98 & 4.03 & -0.690 & 0.491 \\
\hline Brand loyalty & 3.88 & 3.82 & 0.675 & 0.501 \\
\hline Total & 3.85 & 3.85 & -0.025 & 0.980 \\
\hline
\end{tabular}

*Significant level 0.05

The results of hypothesis test for the influencing of education to brand equity, using t-test with significant level 0.05 , showed that there was a significant difference in attitude towards only brand loyalty dimensions, as shown Table V.

TABLE V: EDUCATION AND BRAND EQUITY

\begin{tabular}{|l|c|c|c|c|}
\hline \multirow{2}{*}{ Brand Equity } & \multicolumn{2}{|c|}{$\begin{array}{c}\text { Mean of } \\
\text { education }\end{array}$} & \multicolumn{2}{c|}{} \\
\cline { 2 - 6 } & $\begin{array}{c}\text { Grade } \\
7-9\end{array}$ & $\begin{array}{c}\text { Grade } \\
10-12\end{array}$ & $t$ & Sig. \\
\hline Brand awareness & 3.57 & 3.54 & 0.346 & 0.730 \\
\hline Perceived quality & 4.00 & 4.01 & -0.115 & 0.908 \\
\hline Brand associations & 3.99 & 4.03 & -0.582 & 0.561 \\
\hline Brand loyalty & 3.73 & 3.89 & -1979 & $0.050 *$ \\
\hline \multicolumn{7}{|c|}{ Total } & 3.82 & 3.87 & 0.768 & 0.443 \\
\hline *Significance at 0.05 & &
\end{tabular}

The results of hypothesis test for the influencing of household income to brand equity, using one-way ANOVA with significant level 0.05 , showed that there was a significant difference in attitude towards only brand awareness dimensions, as shown Table VI.

\begin{tabular}{|l|c|c|c|c|c|c|}
\hline \multicolumn{7}{|c|}{ TABLE VI: INCOMES OF PARENTS AND BRAND EQUTY } \\
\hline $\begin{array}{c}\text { Consu } \\
\begin{array}{c}\text { mer's attitude } \\
\text { toward the brand } \\
\text { equity }\end{array}\end{array}$ & \begin{tabular}{c}
$<$ \\
\cline { 2 - 7 }
\end{tabular} & $\begin{array}{c}20,001-40,00 \\
0\end{array}$ & $\begin{array}{c}40,001- \\
60,000\end{array}$ & $\begin{array}{c}> \\
60,001\end{array}$ & $\mathrm{~F}$ & Sig \\
\hline Brand awareness & 3.71 & 3.48 & 3.45 & 3.57 & 3.554 & $0.015^{*}$ \\
\hline Perceived quality & 3.99 & 3.97 & 4.07 & 4.17 & 1.131 & 0.337 \\
\hline $\begin{array}{l}\text { Brand } \\
\text { associations }\end{array}$ & 3.99 & 3.99 & 4.11 & 4.17 & 0.970 & 0.407 \\
\hline Brand loyalty & 3.94 & 3.77 & 3.86 & 3.86 & 1.539 & 0.204 \\
\hline
\end{tabular}

\section{DISCUSSION}

The results indicated that the demographics including the differences of gender, education, and household income have a significant influence on consumer behavior, similar to the study of You QS, Wu LJ, Duan JL, Luo YX, Liu LJ, and et al. [6]. As similar to Anyanee [7], the most frequent reason for wearing eyeglasses is myopia. For hypothesis test for the influencing of demographics on brand equity, the results indicated that different education and household income levels have different influences on attitude towards brand equity, particularly on brand awareness, and brand loyalty dimension, which were similarly to the previous study by Wannapa [14].

\section{RECOMMENDATION}

Regarding the results that the main reason to purchase eyeglasses at optical business is a specialist service, the owner should support staff for the optician training project to be more specialized in order to improve investigating process and enhance quality of service to customers. This will recognize customer in quality of product and increase shop's brand association. In addition, the study found that consumer purchasing budget is mostly fewer than 2,000 Baht, thus price and quality standard allocations are necessary to create variety of products fitting to ranges of target groups.

\section{SUGGESTION}

This study only collected data from secondary and high school students. For the further study, other groups of consumers such as graduated students, or company workers should be studied. Also, at least 1-year study follow up should be performed to limit time to complete the questionnaires, focus on specialized aspects and improve business plan from previous study. Moreover, researchers should study in Integrated Marketing Communication: IMC in order to identify the types of marketing communication methods influencing on optical business plan and consumer's branding attitude to increase comparative advantages for optical business in Thailand.

\section{REFERENCES}

[1] J. Fanning, S. P. Mullen, E. McAuley, "Increasing physical activity with mobile devices: A meta-analysis," Journal of Medical Internet Research, vol.14, no. 6, 2012.

[2] Myopia in children-ophthalmologist Thailand. [Online]. Available: http://www.thairath.co.th/content/279692

[3] Euro Monitors International. (2014). [Online]. Available: http://www.euromonitor.com/eyewear-in-thailand/report

[4] W. Lassar, B. Mittal, and A. Sharma, "Measuring customer-based brand equity," Journal of Consumer Marketing, vol. 12, issue 4, p. 11, 1995. 
[5] P. Kotler, Marketing Management, 9th ed. New Jersey: Prentice Hall: Upper Saddle River, 1997.

[6] Q. S. You, L. J. Wu, J. L. Duan, Y. X. Luo, L. J. Liu et al., "Factors associated with myopia in school children in China: The Beijing childhood eye study," PLOS ONE, vol. 7, no. 12, 2012.

[7] H. Anyanee, "Factor affecting the consumers' choices of optical glasses in shopping malls, Mueang District, Chiang Mai Province," Master of Economics, thesis, Chiang Mai University, Thailand, 2009.

[8] J. Moon, D. Chadee, and S. Tikoo, "Culture, product type, and price influences on consumer purchase intention to buy personalized products online," Journal of Business Research, vol. 61, iss. 1, pp. 31-39, 2008.

[9] P. Kotler, Marketing Management: Analysis, Planning, Implementation and Control, 3rd ed. Prentice Hall International, 1997.

[10] A. Martensen and L. Grønholdt, "Understanding and modeling brand equity," Asian Journal on Quality, vol. 4, iss. 2, pp.73-100, 2003.

[11] D. A. Aaker, Managing Brand Equity: Capitalizing on the Value of a Brand Name, New York, NY: Free Press, 1991.

[12] H. Assael, Consumer Behavior: A Strategic Approach, New York: Houghton Miffin, 2004.

[13] R. E. Rios and H. E. Riquelme, "Brand equity for online companies," Marketing Intelligence \& Planning, vol. 26, iss. 7, pp. 719-742, 2008.

[14] W. Wannapa, "Effect of brand equity on fashion contact lens consumer behavior," Master of management and innovation, King Mongkut's University of Technology Thonburi, Bangkok, Thailand, 2008.

[15] G. A. Churchill Jr., "A paradigm for developing better measures of marketing constructs," Journal of Marketing Research, vol. 16, pp. 64-73, 1979.

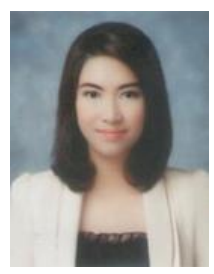

Piyachat Laoviwat finished her bachelor's degree in business administration from Bangkok University of Thailand in 2007. Currently, she is studying in master degree of business administration (M.B.A.), College of Graduate Study in Management Khon Kaen University, Bangkok Campus and is working her own optical business (Wanfah optical store) in Bangkok, Thailand.

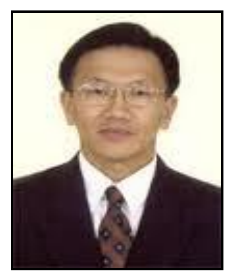

Pramote Suppapanya graduated with a Ph.D. degree in agricultural and resource economics from University of Hawaii at Manoa, U.S.A. He is a member faculty of College of Graduate Study in management at Khon Kaen University. He taught business research methodology and strategic management.

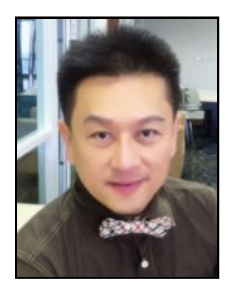

Khanchitpol Yousapronpaiboon has been an assistant professor of marketing at College of Graduate Study in Management at Khon Kaen University for 14 years, where he taught marketing management and service marketing management courses at master and doctoral levels. He received an excellence teaching award of Khon Kaen university in 2003. He gained his DBA degree from Nova Southeastern University of the H. Wayne Huizenga's School of Business \& Entrepreneurship. He worked in Bangkok Bank Public Company Limited for 10 years. He is the honorary advisor; the secretary of the senate standing committee on education; and sub-standing committee on the follow up and evaluation preparation of ASEAN community, the senate standing committee on education in Thailand. He is also a part-time lecturer of marketing management and service marketing management courses at Chiang Mai University and Ubon Ratchatani University in Thailand. 